\title{
Effect of Dietary Protein Level on Alanine Aminotransterase Activity in Liver and Kindney of Growing Chicks
}

\author{
Keiichi Tanaka, Norio Tokita, Shigeru Ohtani and Kakichi Shigeno \\ Faculty of Agriculture, Gifu University, Kakamigahara-shi, Gifu 504
}

The influence of nutritional or physiological factors on gluconeogenesis has not been extensively investigated in the chicken, In almost all the published studies, interest has been centered on factors affecting the post-embryonic developmental changes in the activities of liver enzymes associated with gluconeogenesis in the chicken ${ }^{1 \sim 4)}$. On the other hand, compared with mammals, blood glucose level in the chicken is markedly higher and is maintained at a high level (it only drops by $20 \%$ ) even after prolonged periods of fasting ${ }^{5}$. It is possible that the chicken may have some mechanisms to maintain their blood glucose level, that is, it is probably capable of producing glucose from non-carbohydrate precusors such as gluconeogenic amino acids. In fact, it has been observed that chicks fasted or fed high-protein diet had elevated glucose produced from non-carbohydrates $e$. g. alanine ${ }^{6,7}$. The enzymes initially involved in the process are the aminotransferases which convert such amino acids into their $\alpha$-keto acids, $i$. e. pyruvate and oxaloacetate. Similary, $\mathrm{KREBS}^{8}$. showed that the sites of regulation of gluconeogenesis exist at the initial steps in the degradation of gluconeogenic amino acids. Most of the studies available on the influences of diets and the mechanism by which enzymatic adaptations occur, have been carried out mainly on mammals. This being the case, we therefore investigated the effects of dietary protein level on activities of alanine amionotransferase in the liver and kidney of growing. chicks.

\section{Materials and Methods}

Arimals and diets: Day-old male White Leghorn chicks obtained from a local hatchry (Goto Poulty Farm, Gifu) were used in this study. They were housed in electrically-heated pens with raised wire floors and fed commercial chick starter ad libitum for the first 7 days. At this time, all the chicks were individually wing-banded and assigned to the various. treatments with five chicks each. The composition of experimental diets is shown in Table 1. They were formuateld isocalorically by holding the carbohydrate content and at the same time inversely varying the protein and carbohydrate. Feeding was done from the 8 th to the 15 th day, at which time the birds were killed in the fed state. Feed and water were made available at all times.

Tissue preparation and enzyme assay: At the termination of the experiment, the chicks were weighed and then killed by decapitation. Liver and kidney were rapidly removed, weighed and placed immediately in an ice-cold $0.25 \mathrm{M}$ sucrose solution containing $1 \mathrm{mM}$ EDTA. After blotting dry, a portion of the tissue was weighed and homogenized in 20 
TANAKA et al.: Dietary protein and alanine aminotransferase activity

Table 1. Compsition of experimental diets

\begin{tabular}{|c|c|c|c|c|}
\hline Ingredient & Diet 1 & Diet 2 & Diet 3 & Diet 4 \\
\hline Casein mixture ${ }^{1)}$ & 8.9 & $\begin{array}{c}(\%) \\
17.6\end{array}$ & 17.6 & 17.6 \\
\hline Casein & - & - & 15.8 & 31.6 \\
\hline Sucrose & 76.1 & 67.3 & 49.2 & 31.3 \\
\hline Corn oil & 1.8 & 1.8 & 1.8 & 1.8 \\
\hline Cellulose & 7.0 & 7.1 & 9.4 & 11.5 \\
\hline Mineral mixture ${ }^{2)}$ & 5.0 & 5.0 & 5.0 & 5.0 \\
\hline Vitamin AD mixture $\left.{ }^{3}\right)$ & 0.5 & 0.5 & 0.5 & 0.5 \\
\hline Vitamin B mixture ${ }^{4)}$ & 0.5 & 0.5 & 0.5 & 0.5 \\
\hline Choline chloride & 0.2 & 0.2 & 0.2 & 0.2 \\
\hline Crude protein $(\%)^{5)}$ & 7.9 & 15.6 & 29.6 & 43.5 \\
\hline Metabolizable energy $\left.(\mathrm{kcal} / 100 \mathrm{~g})^{6}\right)$ & 326 & 326 & 326 & 326 \\
\hline \multicolumn{5}{|c|}{ Percentage of energy (ME base) } \\
\hline Protein & 10 & 20 & 40 & 60 \\
\hline Carbohydrate & 85 & 75 & 55 & 35 \\
\hline Fat & 5 & 5 & 5 & 5 \\
\hline
\end{tabular}

1) $90.0 \%$ casein, $5.4 \%$ L-arginine, $1.7 \%$ DL-methionine, $2.0 \%$ glycine.

2) $14.1 \% \mathrm{NaCl}, 27.1 \% \mathrm{~K}_{2} \mathrm{HPO}_{4} \cdot 3 \mathrm{H}_{2} \mathrm{O}, 21.8 \% \mathrm{CaHPO}_{4} \cdot 2 \mathrm{H}_{2} \mathrm{O}, 25.2 \% \mathrm{CaCO}_{3}, 8.6 \%$ $\mathrm{MgSO}_{4} \cdot 7 \mathrm{H}_{2} \mathrm{O}, 2.3 \% \mathrm{FeSO}_{4} \cdot 7 \mathrm{H}_{2} \mathrm{O}, 0.666 \% \mathrm{MnSO}_{4} \cdot 4 \mathrm{H}_{2} \mathrm{O}, 0.067 \% \mathrm{KI}, 0.021 \% \mathrm{ZnSO}_{4}$, $0.025 \% \mathrm{CuSO}_{4} \cdot 5 \mathrm{H}_{2} \mathrm{O}$.

3) Vitamin A 5000, vitamin $\mathrm{D}_{3} 1000$ (IU or ICU/g mixture).

4) Thiamine- $\mathrm{HCl} 1200$, riboflavin 120 , niacin 1000 , phyridoxine- $\mathrm{HCl} 80$, Ca-pantothenate 400 , inositol 4000 , folic acid $50, \mathrm{DL}-\alpha$-tocopherol $200, \beta$-aminobenzoic acid 1000 , biotin 6 , menadione 50 , cyanocabalmin 0.5 , lactose $91893.5(\mathrm{mg} / 100 \mathrm{~g}$ mixture).

5) Calculated value.

6) Calculated value. Casein mixture 3.9, casein 4.1, corn oil and Sucrose $3.7(\mathrm{kcl} / \mathrm{g})$.

volumes of the same medium. Homogenates were centrifuged at $600 \times \mathrm{g}$ for 10 minutes. One aliquot of supernatant was used to measure the activities of total tissue alanine aminotransferase (AAT) and phosphoenolpyruvate carboxykinase (PEPCK), the second aliquot was recentrifuged at $105,000 \times \mathrm{g}$ for 60 minutes. Supernatant from this high-speed centrifugation was used to measure the activities of AAT and PEPCK in soluble fraction. The activities of these enzymes in particulate fraction were assumed to represent the difference between the activities of particulate and soluble fraction. All operations were performed at $4^{\circ} \mathrm{C}$. Samples for total enzyme activities were rapidly frozen, and stored for no more than one day. They were then thawed and sonicated in ice-cold water immediately before assay. Enzymes activities in soluble fraction was measured the same day the chicks were killed.

The activities of AAT and PEPCK were determined according to previously described methods by BERGMEYER and BerNT ${ }^{9)}$ and JomaIn-BAUm et al. ${ }^{10)}$. Assays were carried out at $25^{\circ} \mathrm{C}$ and enzyme activities were expressed as $\mu$ moles $\mathrm{NADH}$ oxidized $/ \mathrm{min} / \mathrm{g}$ wet tissue. Protein was determined by the method of LowRY et $a^{111}$. using bovine serum albumin as the standard. Enzyme activity was also expressed on the basis of the protein. Since concentrations of protein in the organs changed only minimally in the various treatments, the 
date on them are not presented. Serum was separated by centrifugation from the blood collected at killing time. It was used in the determinations of the non-esterified fatty acids (NEFA) and glucose level in serum which were carried out in accordance with the simplified procedures suggested in the mini-manual enclosed with the NEFA-Test Kit and the Glucose C-Test Kit from a commercial chemical manufacture-distributor (Wako Junyaku Kogyo K. K).

Statistical analysis: Tukey's procedure ${ }^{12)}$ was used to test treatment mean when significant $(\mathrm{P}<0.05)$ treatment $\mathrm{F}$ values were found.

\section{Results and Discussion}

The influence of dietary protein level on body weight gain, liver and kidney weights is shown in Table 2.

Increasing the level of dietary protein significantly increased body weight gain although there was no significant difference between $10 \%$ and $20 \%$ energy from protein.

Liver weight, expressed as percentage of body weight, was not affected by dietary protein level. Kidney weight per $100 \mathrm{~g}$ body weight in chicks fed diet containing $10 \%$. energy from protein was significantly lower than in those fed other experimental diets.

The influence of dietary protein level on concentrations of glucose and NEFA in serum is shown in Table 3.

The concentration of NEFA in serum was significantly increased when the percentage of energy from dietary protein was increased from $10 \%$ to $20 \%$, however, when the per-

Table 2. Effect of percentage of energy from protein on energy intakes, body weight gain, liver and kidney weights of growing chicks

\begin{tabular}{|c|c|c|c|c|c|}
\hline & \multicolumn{4}{|c|}{ Percentage of energy from protein (ME base) } & \multirow{2}{*}{$\mathrm{P}^{1)}$} \\
\hline & 10 & 20 & 40 & 60 & \\
\hline Energy intakes (kcal/chick/day) & 48.9 & 48.2 & 44.4 & 45.7 & \\
\hline Body weight gain (g) & $62.2 \pm 3.6^{2) a}$ & $65.5 \pm 1.5^{\mathrm{a}}$ & $73.2 \pm 3.6^{b}$ & $89.0 \pm 3.3^{c}$ & $\mathrm{P}<0.01$ \\
\hline Liver weight ( $\mathrm{g} / 100 \mathrm{~g}$ body weight) & $2.4 \pm 0.3$ & $3.0 \pm 0.5$ & $2.8 \pm 0.2$ & $2.5 \pm 0.1$ & N.S. \\
\hline Kidney weight ( $g / 100 \mathrm{~g}$ body weight) & $0.7 \pm 0.1^{\mathrm{a}}$ & $1.0 \pm 0.1^{\mathrm{b}}$ & $1.0 \pm 0.1^{\mathrm{b}}$ & $1.1 \pm 0.1^{\mathrm{b}}$ & $\mathrm{P}<0.01$ \\
\hline
\end{tabular}

1) Probability of a significant treatment effect. N. S. = Not significant.

2) Mean \pm S. D. for five chicks.

a, b, c Mean values in the same horizontal column having different superscript letters are significantly different from one another $(\mathrm{P}<0.01)$.

Table 3. Effect of percentage of energy from protein on concentrations of glcose and NEFA in serum of growing chicks

\begin{tabular}{|c|c|c|c|c|c|}
\hline & \multicolumn{4}{|c|}{ Percentage of enegy from protein (ME base) } & \multirow{2}{*}{$\left.\mathrm{P}^{1}\right)$} \\
\hline & 10 & 20 & 40 & 60 & \\
\hline Glucose $(\mathrm{mg} / 100 \mathrm{ml})$ & $223.2 \pm 6.4^{2) \mathrm{a}}$ & $243.2 \pm 8.8^{b}$ & $215.4 \pm 8.8^{\mathrm{a}}$ & $141.2 \pm 8.8^{c}$ & $\mathrm{P}<0.01$ \\
\hline NEFA $(\mu \mathrm{Eq} / l)$ & $364.0 \pm 37.3^{\mathrm{a}}$ & $441.0 \pm 37.2^{\mathrm{b}}$ & $296.0 \pm 44.9 c$ & $309.0 \pm 27.3 c^{c}$ & $\mathrm{P}<0.01$ \\
\hline
\end{tabular}

1) Probability of a significant treatment effect.

2) Mean \pm S. D. for five chicks.

$a, b, c$, Mean values in the same horizontal column having different superscript letters are significatnly different from one another $(P<0.05)$. 
Table 4. Effect of percentage of energy from protein on AAT and PEPCK activities in liver and kindney of growing chicks

\begin{tabular}{|c|c|c|c|c|c|}
\hline & \multicolumn{4}{|c|}{ Parcentage of energy from protein (ME base) } & \multirow{2}{*}{$\mathrm{P}^{1)}$} \\
\hline & 10 & 20 & 40 & 60 & \\
\hline AAT activity & \multicolumn{4}{|c|}{ 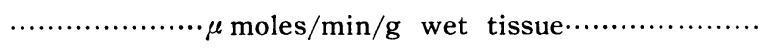 } & \\
\hline \multicolumn{6}{|l|}{ Liver } \\
\hline Particulate fraction & $0.64 \pm 0.11^{2) a}$ & $1.51 \pm 0.23^{b}$ & $2.60 \pm 0.41^{\mathrm{c}}$ & $5.16 \pm 0.55^{d}$ & $\mathrm{P}<0.01$ \\
\hline Soluble fraction & $0.33 \pm 0.03^{\mathrm{a}}$ & $0.38 \pm 0.08^{\mathrm{a}}$ & $0.52 \pm 0.08^{\mathrm{a}}$ & $1.29 \pm 0.28^{b}$ & $\mathrm{P}<0.01$ \\
\hline \multicolumn{6}{|l|}{ Kindney } \\
\hline Particulate fraction & $3.04 \pm 0.26^{\mathrm{a}}$ & $4.72 \pm 0.34^{\mathrm{b}}$ & $9.39 \pm 0.37^{c}$ & $19.77 \pm 0.38^{d}$ & $\mathrm{P}<0.01$ \\
\hline Soluble traction & $0.57 \pm 0.05^{\mathrm{a}}$ & $1.07 \pm 0.15^{\mathrm{b}}$ & $1.47 \pm 0.17^{\circ}$ & $2.19 \pm 0.03^{\mathrm{d}}$ & $\mathrm{P}<0.01$ \\
\hline \multicolumn{6}{|l|}{ PEPCK activity* } \\
\hline \multicolumn{6}{|l|}{ Liver } \\
\hline Particulate fraction & $1.43 \pm 0.61$ & $1.21 \pm 0.44$ & $1.23 \pm 0.22$ & $1.35 \pm 0.31$ & N.S. \\
\hline \multicolumn{6}{|l|}{ Kidney } \\
\hline Particulate fraction & $1.13 \pm 0.55$ & $1.16 \pm 0.43$ & $1.11 \pm 0.41$ & $1.11 \pm 0.34$ & N.S. \\
\hline
\end{tabular}

1) Probability of a significant treatment effect. N.S.= Not significant.

2) Mean \pm S. D. for five chicks.

a, b, c, d, Mean values in the same horizontal column having different superscript letters are significantly different from one another $(p<0.05)$.

* Most of PEPCK activity in liver and kidney of chicks was located in the particulate fraction. Consequently only particulate fraction was shown in the table.

centage of energy from dietary protein was increased from $20 \%$ to $40 \%$ or $60 \%$, the concentration significantly decreased. Although glucose concentration in serum in chicks fed diet containing $20 \%$ energy from protein was significantly higher than in those fed diets containing $10 \%$ and $40 \%$ energy from protein, increasing it to $60 \%$ cause the glucose concentration to decrease significantly.

Table 4 shows the influence of dietary protein level on the AAT and PEPCK activities in liver and kidney of growing chicks.

AAT activity, expressed per $\mathrm{g}$ tissue, was higher in kidney than in liver, and was higher in particulate fraction than in soluble fraction. Approximately $85 \%$ to $90 \%$ of activity in kidney was associated with the particulate fraction and only $10 \%$ to $15 \%$ with the soluble fraction. Increased protein in the diet resulted in a significant increase in AAT activity in both fractions of kidney, although the magnitude of change in the particulate fraction was greater than that observed in the soluble fraction. In liver, approximately $65 \%$ to $80 \%$ of activity was associated with the particulate fraction and $20 \%$ to $35 \%$ with the soluble fraction. As observed in kidney, increased protein in the diet resulted in a significant increase in AAT activity in the particulate fraction of liver. On the other hand, AAT activity in the soluble fraction of liver tended to increase, although not significantly, when the percentage of energy from dietary protein increased from $10 \%$ to $40 \%$. However, chicks fed diet containing $60 \%$ energy from protein had significantly higher AAT activity in the soluble fraction of liver than those fed diets containing from $10 \%$ to $40 \%$ energy from protein.

The cellular distribution of AAT presented in this paper markedly differ from those of SARKER'S ${ }^{13,14)}$, SwICK et al. ${ }^{15,16)}$ and DeRosA and SwICK' ${ }^{17)}$ experiments with rats. They have demonstrated that in rats, most of AAT activity in liver was located in the cytosol fraction 


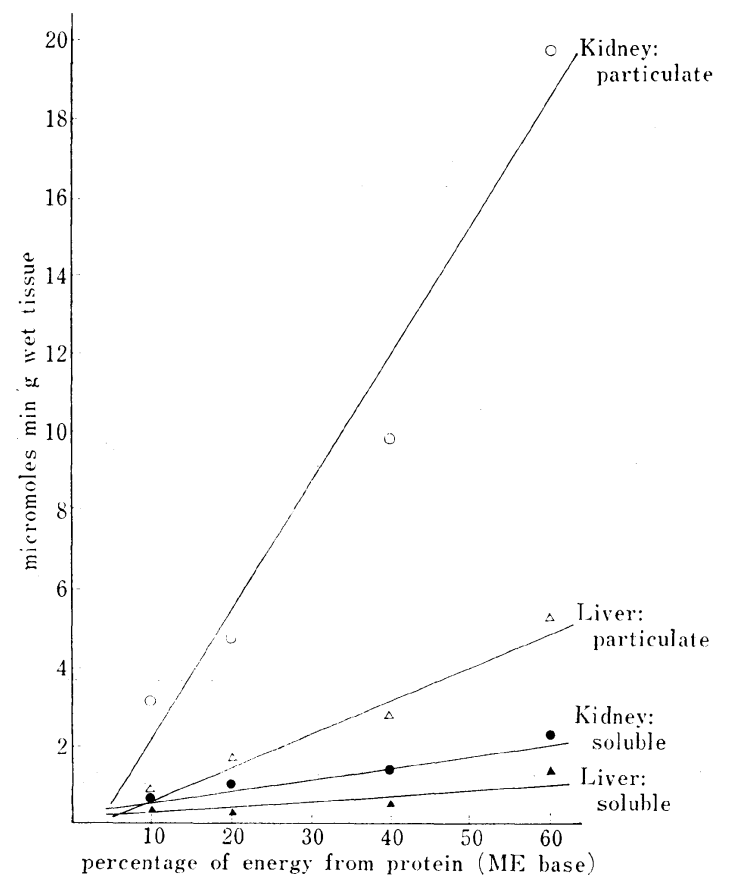

Figure 1. Regression lines relating AAT activity in liver and kidney of chicks to the percentage of energy from protein in diets. Each point represents the mean for five chicks. Equations for liver particulate and soluble fractions were $\mathrm{Y}=$ $0.087 \mathrm{X}-0.351(\mathrm{r}=0.982, \mathrm{p}<0.05)$ and $\mathrm{Y}$ $=0.018 \mathrm{X}-0.026(\mathrm{r}=0.833)$, respectively. Equations for kindney particulate and soluble fractions were $\mathrm{Y}=0.337 \mathrm{X}$ $1.494(\mathrm{r}=0.971, \mathrm{p}<0.05)$ and $\mathrm{Y}=0.031 \mathrm{X}$ $+0.242(\mathrm{r}=0.970, \mathrm{p}<0.05)$, respectively.

and also, that there was little activity of AAT in kidney. DeRosa and Swick ${ }^{17)}$ proposed that the main function of the mitochondrial AAT is to from pyruvate from alanine while the cytosolic enzyme may mainly be involved in the reverse reaction. In the present experiment, AAT and PEPCK necessary for the conversion of alanine to pyruvate, to oxaloacetate and to phosphoenolpyruvate, are mostly present in the particulate (mitochondrial) fraction in liver and kidney of chicks, unlike in liver of rats $^{12 \sim 15)}$ and guinea-pigis). This restricts the conversion of oxaloacetate to phosphoenolpyruvate in the cytosol fraction, although permitting this reaction to take place in the mitochondrial fraction, phosphoenolpyruvate, after being formed in the mitochondrial fraction, can be transported to the cytosol fraction and be utilized for glucose synthesis. It is assumed, in fact, that phosphoenolpyruvate can also pass through the mitochondrial membrane ${ }^{18}$. The reaction catalyzed by the AAT is the initial step in the reaction sequences in gluconeogenesis for alanine ${ }^{8,19)}$, and AAT plays an important role in the regulation of gluconeogenesis from alanine. In the present experiment, increased protein, at the expense of carbohydrate in the diet, resulted in a linear increase in AAT activity in the particulate (mitochondrial) fraction of liver and kidney, although the enzyme activity in kidney was greater than that observed in liver (Fig. 1). On the other hand, the activity of liver and kidney PEPCK, which is the most important enzyme in the regulation of gluconeogenesis, was not affected by the dietary protein level. Furthermore, in the present experiment, glucose concentration in serum was decreased when chicks fed diet containing $60 \%$ energy from protein, although, increasing from $10 \%$ to $40 \%$ energy from the dietary protein did not decrease glucose level in serum. Therefore, from the results presented in this paper, no definite conclusions can be draw as to whether a close parallelism between the increased rate of gluconeogenesis and increased activity of AAT in liver and kidney of chicks exists or not.

\section{Summary}

The influence of increasing dietary protein level, at the expense carbohydrate, on alanine aminotransferase (AAT) activity in liver and kidney of growing chicks was investigated. 
Approximately $85 \%$ to $90 \%$ of AAT activity in kidney was associated with the particulate fraction and only $10 \%$ to $15 \%$ with the soluble fraction. In liver, approximately $65 \%$ to $80 \%$ of AAT activity was associated with the particulate fraction and $20 \%$ to $35 \%$ with the soluble fraction.

Increasing dietary protein, at the expense of carbohydrate, resulted in a linear increase in AAT activity in the particulate fraction of liver and kidney, although the magnitude of change in kidney was greater than that observed in liver. AAT activity in the soluble fraction of kidney was significantly increased when the dietary protein level increased. On the other hand, AAT activity in the soluble fraction of liver tended to increase, although insignificantly, when the percentage of energy from dietary protein increased from $10 \%$ to $40 \%$. However, chicks fed diet containing $60 \%$ energy from protein had significantly higher AAT activity in the soluble fraction of liver than those fed diets containing from $10 \%$ to $40 \%$ energy from protein.

Activity of phosphoenolpyruvate carboxykinase in the particulate fraction of liver and kidney was not affected by the dietary protein level.

\section{Literature}

1) Alled, J. B. and K. L. Roehrig: J. Nutr. 100, 615-622, 1970.

2) Felicioli, R. A., F. Gabrielli and C. A. Rossi: Eur. Biochem. 3, 19-24, 1967.

3) Madappally, M. M., R. J. Paquest, M. A. Mehlman, A. Myron and R. B. Tobin: J. Nutr. 101, 755$760,1971$.

4) Raheja, K. L., J. G. Snedecor and R. A. Freedland: Comp. Biochem. Physiol. 398, 237-246, 1971.

5) SARKer, N. K.: Life Sci. 10. 293-300, 1971.

6) Veiga, J. A. S., E. S. Roselino and R. H. Migliorini: Am. J. Physiol. 234, R 115-R 121, 1978.

7) Swick, R. W., P. L. Barnstein and J. L. Stange: J. Biol. Chem. 240, 3341-3345, 1965.

8) Krebs, H. A.: Proc. Roy. Soc. B. 159, 565-569, 1964.

9) Bergmeyer, H. V. and E. Bernt: Methods of Enzymatic Analysis. 2nd ed. (Bergmeyer, H. V. ed) 752-756, Academic Press, New York, U. S. A., 1974.

10) Jomain-Baum, M., V. L. Schramn and R. W. Hanson: J. Biol. Chem. 251, 37-44, 1976.

11) Lowry, O. H., N. J. Rosenbrough, A. L. Farr and R. J. Randall: J. Biol. Chm. 193, $265-275,1951$.

12) Yoshida, M.: Design of Experiments for Animal Husbandry. (Yoshida, M. ed) 85, Yohkendo Press, Tokyo, Japan, 1975.

13) SARKer, N. K.: Int. J. Biochem. 5, 375-381, 1974.

14) SARker, N. K.: Int. J. Biochem. 8, 427-431, 1977.

15) Swick, R. W., P. L. Barnstein and J. Stange: J. Biol. Chem. 240, 3334-3340, 1965.

16) Swick, R. W., P. L. Barnstein and J. Stange: J. Biol. Chem. 240, 3341-3345, 1965,

17) DeRosa, G. and R. W. Swick: J. Biol. Chem. 250, 7961-7967, 1975.

18) Garber, A. J. and F. J. Ballard: J. Biol. Chem. 244, 4696-4703, 1969. 
飼料中蛋白質含量が成長中ヒナの肝蔵および腎臓におけるアラニン・ アミノトランスフェラーゼ活性におよぼす影響について

\author{
田中桂一・時田昇臣・大谷 滋・重野嘉吉 \\ 岐阜大学農学部・各務原市 T504
}

飼料中の蛋白質含量が成長中のヒナの肝臓および腎臓 おける alanine aminotransferase (AAT) 活性を検討 した。

腎臓における AAT 活性の $85 \%$ 90\% は particulate 画分中に, 残りの $10 \%$ 15\% が soluble 画分中に分布 していた。肝蔵においては, AAT 活性の $65 \%$ ～ $80 \%$ は particulate 画分中に, そして 20〜35\% は particulate 画分中に分布している。

飼料中の蛋白質含量が増加すると肝臓および腎臟の particulate 画分中の AAT 活性注線的に増加し, そ してその增加の程度は朋臓に比較し腎臓の方が大きかっ た。腎臓での soluble 画分中の AAT 活性は, 飼料中
の蛋白質含荲が増加するのに伴い，統計的に有意な増加 を示した。一方肝蔵での soluble 画分中の AAT 活性 は, 飼料中の全エネルギーのうち蛋白質の占める割合が. $10 \%$ から $40 \%$ までの増加では, 統計的に有意なもので なかったが増加する傾向にあった。しかし飼料中の全エ. ネルギーのうち 蛋白質の 占める割合が $60 \%$ に増加した 時の活性は，飼料中の蛋白質によるエネルギーの割合が $10 \%$ から $40 \%$ の封の活性に比べ，統計的に有意に高い 值を示した。

肝蔵および腎臓の particulate 画分中の phophoenolpyrvate carboxykinase 活性は 飼料中の蛋白質含量に よる影響はみられなかった。

（家禽会誌，18，164～170，1981） 